ROCZNIKI TEOLOGICZNE

Tom LXVI, zeszyt 9 - 2019

DOI: http://dx.do.org/10.18290/rt.2019.66.9-1

\title{
PERSONALISTYCZNY CHARAKTER CHRYSTOFANII PASCHALNYCH W UJECCIU KS. PROF. EDWARDA KOPCIA (1918-1999)
}

\author{
THE PERSONALISTIC CHARACTER OF THE PASCHAL CHRISTOPHANIES \\ ACCORDING TO REV. PROF. EDWARD KOPEĆ (1918-1999)
}

A b s t r a c t. The article presents the personalistic character of the Paschal Christophanies according to Fr. Prof. Edward Kopeć, the nestor of fundamental theology in Poland. The topic of discussion was presented in four points: 1. Paschal Christophanies as credible signs of the resurrection; 2. The personal dimension of the appearance of the Resurrected; 3 . The personalistic character of recognizing him; 4. Personalistic aspects of the mission, paschal faith and testimony.

Starting from the conviction that the Paschal Christophanies are the most important signs of the credibility of Jesus' Resurrection, Fr. E. Kopeć always treats them as real and objective events and presents their many aspects. Above all, the Paschal Christophanies, similar to the Old Testament theophanies, have a personal character for the Lublin professor. The encounters of the resurrected Lord with his disciples are an expression of interpersonal relationships, which are expressed by the essential elements of the majority of Christophanies, namely: his appearing, recognizing him, and the mission. Kopeć's pioneering development of the Paschal Christophanies in personalist terms correlates with their historical character, which is essential for demonstrating the credibility of Christ's Resurrection.

Key words: Edward Kopeć; Jesus Christ; resurrection; Paschal Christophanies.

Translated by Jan Kobytecki

Ks. dr hab. Jacenty MASTEJ, prof. KUL - kierownik Katedry Chrystologii i Eklezjologii Fundamentalnej; dyrektor Instytutu Teologii Fundamentalnej KUL; wykładowca teologii fundamentalnej w WSD w Rzeszowie; adres do korespondencji - e-mail: jmastej@kul.pl 
Personalistyczny charakter współczesnej teologii fundamentalnej jest bezdyskusyjny. U początku personalistycznego ujmowania najpierw apologetyki, a następnie teologii fundamentalnej w Polsce stoi ks. prof. Edward Kopeć ${ }^{1}$. $\mathrm{W}$ ubiegłym roku obchodziliśmy 100. rocznicę jego urodzin, a w tym roku obchodzimy 20. rocznicę jego śmierci. Mając na uwadze powyższe racje, chcemy powrócić do twórczości naukowej nestora teologii fundamentalnej w Polsce oraz pioniera lubelskiej szkoły teologii fundamentalnej ${ }^{2}$.

Personalistyczne elementy teologii fundamentalnej w ujęciu ks. prof. Edwarda Kopcia uwyraźnił ks. prof. Marian Rusecki. W artykule „Elementy personalistycznej teologii fundamentalnej w ujęciu Edwarda Kopcia"”3 omawia on genezę poglądów nestora polskiej teologii fundamentalnej, jego personalistyczną koncepcję Objawienia Bożego, osobowy wymiar cudu oraz wiarę jako osobowe spotkanie. Rusecki pomija jednak kwestię osobowego charakteru zmartwychwstania Jezusa Chrystusa, dlatego przedmiotem niniejszego artykułu jest personalistyczny charakter chrystofanii paschalnych. Już w tym miejscu trzeba podkreślić, że problematyka rezurekcyjna zajmowała centralne miejsce w twórczości naukowej E. Kopcia. Lubelski profesor, obficie czerpiąc $\mathrm{z}$ teologii niemieckojęzycznej ${ }^{4}$

\footnotetext{
${ }^{1}$ M. RUSECKI, Ksiadz prof. dr hab. Edward Kopeć. Życie i dziatalność naukowo-dydaktyczna, „Roczniki Teologiczno-Kanoniczne” 32(1985), z. 2, s. 7-22; TENŻE, Kopeć Edward, w: Leksykon Teologii Fundamentalnej, red. M. Rusecki i in. Lublin-Kraków 2002, s. 651-653; TENŻE, Kopeć Edward, w: Encyklopedia Katolicka, t. 9, kol. 794-795; TENŻE, O księdzu profesorze Edwardzie Kopciu i jego wktadzie w polska teologie fundamentalna, w: Teologia wobec zjawisk paranormalnych, red. K. Kaucha, J. Mastej, Lublin 2011, s. 5-13; TENŻE, Kopeć Edward, w: Encyklopedia 100-lecia KUL, t. 1, Lublin 2018, s. 541-542; TENŻE, Zagadnienie personalizmu w pracach badawczych Wydziału Teologii KUL (1968-1993), „Roczniki Teologiczne" 43(1996), z. 4, s. 254-255; J. MASTEJ, Dorobek lubelskiej szkoty teologii fundamentalnej w zakresie chrystologii, „Roczniki Teologiczne” 65(2018), z. 9, s. 55-74.

${ }^{2}$ K. KAUCHA, Lubelska szkoła teologii fundamentalnej, w: Encyklopedia 100-lecia KUL, t. 1, Lublin 2018, s. 634-635; K. KAUCHA, Wiarygodność i wiara w ujęciu lubelskiej szkoty teologii fundamentalnej, w: Wiara - wiarygodność, red. D. Wąsek, Kraków 2014, s. 634-635; J. MASTEJ, K. KAUCHA, 100 lat teologii fundamentalnej na KUL, „Przegląd Uniwersytecki” 30(2018), nr 1, s. 22-25.

3 M. RUSECKI, Elementy personalistycznej teologii fundamentalnej w ujęciu Edwarda Kopcia, „Roczniki Teologiczno-Kanoniczne” 32(1985), z. 2, s. 49-85.

${ }^{4}$ H.W. BARTSCH, Das Auferstehuhgszeugnis, sein historisches und sein theologisches Problem, Hamburg 1965; K. BÜRgENER, Die Auferstehung Jesu Christi von Toten, 3. Aufl. Bremen 1976; A. GEENSE, Auferstehung und Offenbarug, Göttigen 1971; B. KLAPPERT, Diskussion um Kreuz und Auferstehung, 3. Aufl. Wuppertal 1968; G. KiTtEL, Die Auferstehung Jesu, Stuttgart 1937; A. KolPING, Wunder und Auferstehung Jesu Christi, Bergen-Enkhein 1969; J. Kremer, Das älteste Zeugnis von der Auferstehung Christi, Stuttgart 1968; G. KocH, Die Auferstehung Jesu Christi, 2. Aufl. Tübingen 1965; K. LeHMann, Jesus Christus ist auferstanden, Freiburg i Br. 1975; F. Mussner, Die Auferstehung Jesu, München 1969; L. SCHEFFCZYK,
} 
i francuskojęzycznej ${ }^{5}$, nadał polskiej posoborowej teologii rezurekcyjnej historiozbawczy wymiar i personalistyczny charakter.

Podjęty w niniejszym artykule temat zostanie zrealizowany w następujących punktach: 1. Chrystofanie paschalne jako wiarygodne znaki zmartwychwstania; 2. Osobowy wymiar ukazywania się Zmartwychwstałego; 3. Personalistyczny charakter rozpoznania; 4. Personalistyczne aspekty misji, wiary paschalnej i świadectwa.

\section{CHRYSTOFANIE PASCHALNE JAKO WIARYGODNE ZNAKI ZMARTWYCHWSTANIA}

Rezurekcja Jezusa Chrystusa jest centralnym wydarzeniem historii zbawienia oraz fundamentalną tajemnicą wiary chrześcijańskiej. Jest ona - co uwyraźnia E. Kopeć - zarazem realnym faktem i zbawczym misterium ${ }^{6}$. Zmartwychwstanie - które jest nadzwyczajnym aktem Bożej wszechmocy, dzięki któremu Jezus przeszedł ze śmierci do nowego życia w uwielbionym ciele przynależy do rzeczywistości nadprzyrodzonej, dlatego wymyka się czysto zmysłowemu spostrzeganiu człowieka ${ }^{7}$. Nikt z ludzi nie był świadkiem samego zmartwychwstania, nikt go nie widział. Tym samym fakt rezurekcji, choć realny, pozostaje niedostępny czysto naturalnemu doświadczeniu człowieka. Jednak wybrane przez Boga osoby mogły w sposób bezpośredni doświadczyć

Auferstehung. Prinzio christlichen Glaubens, Einsiedeln 1976; P. SCHOONENBERG, Wege nach Emmaus. Unser Glaube an die Auferstehung Jesu, GRAZ 1974; B. SPÖRLEIN, Die Leugnung der Auferstehung, Regensburg 1971; U. WILCKENS, Auferstehung. Das biblische Auferstehungszeugnis historisch untersucht und erklärt, Stutgart 1970.

${ }^{5}$ P. Benoît, Passion et résurrection du Seigneur, Paris 1966; J. CANTINAT, Réflexion sur la résurrection de Jésus (d'aprés saint Paul et saint Marc), Paris 1978; J. DANIÉLU, La résurrection, Paris 1969; F.X. DuRRwell, La résurrection de Jésus. Mystere de salut, ed. 3, Paris 1961; P. GUIBERT, Il résurrection le troisième jour, Paris 1975; J. GUITTON, Le problème de Jésus. Divinité et Résurrection, Paris 1953; X. LÉON-DufOuR, Résurrection de Jésus et message pascal, Paris 1971; TENŻE, Sur la résurrection de Jésus, „Recherches de Science Religieuse" 57(1969), s. 583-622; J. SCHMITT, Jésus résuscité dans la prédication apostolique, Paris 1949.

${ }^{6}$ E. KOPEĆ, Wydarzeniowy i misteryjny aspekt zmartwychwstania Chrystusa. W: Teologia naukq o Bogu, Kongres Teologów Polskich, Kraków 1976, s. 225-228; TENŻE, Historiozbawczy charakter zmartwychwstania Chrystusa, „Roczniki Teologiczno-Kanoniczne” 24(1977), z. 4, s. 107-118; TENŻE, Zmartwychwstanie Jezusa Chrystusa jako realny fakt $i$ wydarzenie zbawcze, w: Jezus Chrystus. Historia i tajemnica, red. W. Granat, E. Kopeć, Lublin 1982, s. 246-277.

${ }^{7}$ E. KoPEĆ, Teologia fundamentalna, Lublin 1976, s. 152-153. 
obecności zmartwychwstałego Pana. Dokonało się to dzięki chrystofaniom paschalnym $^{8}$.

Zdaniem E. Kopcia chrystofanie paschalne są następstwem zmartwychwstania oraz jego najważniejszym osobowym znakiem. Świadectwa nowotestamentowe zgodnie potwierdzają fakt chrystofanii (np. Mt 28; Łk 24; J 20 i 21; Mk 16,7.9-20; Dz 1,3; 10,40-41; 13,31; 1 Kor 9,1; 15,6-8; Ga 1,12.16) ${ }^{9}$. Pozwalają one nie tylko uznać realność faktu zmartwychwstania, ale także odsłaniają jego istotę. Chrystofanie są nie tylko Bożą proklamacją zmartwychwstania, ale także jego najważniejszym uwiarygodnieniem ${ }^{10}$.

W relacjach o chrystofaniach istnieją liczne rozbieżności, np. co do liczby świadków, miejsca czy czasu ukazywania się Zmartwychwstałego. Zdaniem przedstawicieli egzegezy liberalnej, rozbieżności te podważają historyczną wartość opisów chrystofanijnych, a co za tym idzie także samego faktu zmartwychwstania. Zdaniem E. Kopcia u podstaw tego przekonania leży niewłaściwe pojmowanie źródeł biblijnych, które są rozumiane jako dokumenty ściśle historyczne. Mając na uwadze cel i charakter przekazów ewangelijnych, łatwo dostrzec, że nie mają one charakteru historyczno-kronikarskiego, ale są przede wszystkim świadectwem wiary, dlatego fakty zostały zinterpretowane historiozbawczo. Ewangeliści czerpali z tradycji apostolskiej oraz kierowali się określonym celem redakcyjnym, jednak podstawą ich narracji były realne wydarzenia, potwierdzone przez wielu wiarygodnych świadków ${ }^{11}$.

Nowotestamentowe świadectwa wielkanocne pozwalają stwierdzić, że chrystofanie paschalne nie miały charakteru powszechnego, ale były skierowane do „wybranych uprzednio przez Boga na świadków” (Dz 10,41). Najstarszy wykaz świadków chrystofanii znajduje się w 1 Liście do Koryntian: „ukazał się Kefasowi, a potem Dwunastu, później zjawił się więcej niż pięciuset braciom równocześnie; większość z nich żyje dotąd, niektórzy zaś pomarli. Potem ukazał się Jakubowi, później wszystkim apostołom. W końcu, już po wszystkich, ukazał się także i mnie jako poronionemu płodowi" (1 Kor 15,5-8). Lista ta jest kontynua-

${ }^{8}$ E. Kopé́, Świadkowie zmartwychwstania Jezusa Chrystusa, „Roczniki TeologicznoKanoniczne" 7(1960), z. 1, s. 5-43; TENŻE, Chrystofania $w$ teologii, w: Encyklopedia Katolicka, t. 3, kol. 302-303.

${ }^{9}$ E. KOPEĆ, Chrystofanie jako znaki zmartwychwstania Chrystusa, ,Roczniki TeologicznoKanoniczne” 25(1978), z. 2, s. 21-29; TENŻE, Zmartwychwstanie Jezusa Chrystusa jako realny fakt $i$ wydarzenie zbawcze, s. 271-273.

10 E. Kopé́, Problematyka zmartwychwstania Chrystusa w apologetyce wspótczesnej, „Collectanea Theologica” 30(1959), s. 89-90.

${ }^{11}$ E. Kopeć, Historiozbawczy charakter zmartwychwstania Chrystusa, s. 110-111; TENŻE, Zmartwychwstanie Jezusa Chrystusa jako realny fakt $i$ wydarzenie zbawcze, s. 261-267. 
cją Credo korynckiego i z wyjątkiem ostatniego zdania należy do tradycji przedPawłowej. Św. Paweł, odwołując się do tradycji pierwotnego Kościoła, wymienia pięć chrystofanii, poczynając od ukazania się Zmartwychwstałego Kefasowi. Jako szóstą chrystofanię Paweł wspomina ukazanie się Chrystusa jemu pod Damaszkiem. W tym przypadku chrystofanie są wymienione w porządku hierarchicznym, a nie chronologicznym. Katalog ten potwierdza istnienie stosunkowo licznej grupy osób, które doświadczyły spotkań ze Zmartwychwstałym. Obszerne opisy chrystofanii przekazują wszyscy ewangeliści, którzy - podobnie jak Paweł wspominają o ukazaniu się Zmartwychwstałego Piotrowi (Mk 16,7; Łk 24, 12.34; J 21,1-23) oraz Dwunastu (Mk 16,14-18; Mt 28, 16-20; J 20,19-20). Wspominają też inne chrystofanie: Marii Magdalenie i innym kobietom (Mt 28,9-10; Mk 16,9-11), samej Marii Magdalenie (J 20,11-18), uczniom idącym do Emaus (Łk 24,33-50; por. Mk 16, 12-13), apostołom i innym uczniom (Łk 24,36-50) oraz grupie siedmiu uczniów nad Morzem Tyberiadzkim (J 21,1-23). Nestor lubelskiej szkoły teologii fundamentalnej w artykule „Świadkowie zmartwychwstania Chrystusa” szczegółowo omawia „listę świadków zmartwychwstania”,12. Ks. Kopeć do chrystofanii paschalnych zalicza także Pawłowe widzenie zmartwychwstałego Pana (por. Dz 9,3-10; Ga 1,12-17) ${ }^{13}$. Nowotestamentowe opisy nie pozwalają odtworzyć chronologicznej kolejności chrystofanii. $Z$ teologicznego punktu widzenia oznacza to, że zmartwychwstały Pan żyje już w rzeczywistości ponadhistorycznej, poza miejscem i czasem ${ }^{14}$.

Nestor teologii fundamentalnej w Polsce zwraca uwagę, że podstawę ewangelijnych narracji o chrystofaniach stanowią dwie preewangelijne tradycje, istniejące w Kościele pierwotnym. Ze względu na miejsce ukazywania się Chrystusa, tradycje te określa się jako galilejską (Mk 16,7; Mt 28,7.16;

\footnotetext{
${ }^{12}$ E. Kopeć, Świadkowie zmartwychwstania Jezusa Chrystusa, s. 22-37.

${ }^{13}$ Warto w tym miejscu przypomnieć, że ks. E. Kopeć uzyskał stopień naukowy doktora habilitowanego na podstawie dorobku naukowego i rozprawy habilitacyjnej „Świadectwo św. Pawła o zmartwychwstaniu Chrystusa”. Rozprawa habilitacyjna została opublikowana w następujących artykułach: Apologia zmartwychwstania Chrystusa w pierwotnej kerygmie apostolskiej, „Roczniki Teologiczno-Kanoniczne” 6(1959), z. 3, s. 57-75; Problematyka zmartwychwstania Chrystusa w apologetyce wspótczesnej, „Collectanea Theologica” 30(1959), s. 83-108; Świadkowie zmartwychwstania Jezusa Chrystusa, „Roczniki Teologiczno-Kanoniczne” 7(1960), z. 1, s. 5-43; Spotkanie św. Pawła z Chrystusem, „Zeszyty Naukowe Katolickiego Uniwersytetu Lubelskiego" 3(1969), z. 1, s. 45-60; Ewangelia św. Pawta jako świadectwo o zmartwychwstaniu Chrystusa, w: Ze wspótczesnej problematyki biblijnej, red. S. Łach, Lublin 1961, s. 93-113 (M. RUSECKI, Ksiadz prof. dr hab. Edward Kopeć. Życie i działalność naukowo-dydaktyczna, „Roczniki Teologiczno-Kanoniczne” 32(1985), z. 2, s. 8).

14 E. KOPEĆ, Problematyka zmartwychwstania Chrystusa $w$ apologetyce wspótczesnej, „Collectanea Theologica” 30(1959), s. 87.
} 
J 21,1-23) i jerozolimską (Łk 24,6.36-52; J 20,19-29) ${ }^{15}$. Reprezentują różne typy chrystologii: galilejska głosi Pana wywyższonego, a jerozolimska Chrystusa zmartwychwstałego ${ }^{16}$. Wprawdzie tradycja galilejska jest starsza, jednak w teologii narracyjnej ewangelistów przeważyła tradycja jerozolimska.

Zawarte w Nowym Testamencie opisy chrystofanijne rzutują na rozumienie samego zmartwychwstania. W oparciu o narracje chrystofanijne E. Kopeć stwierdza, że zmartwychwstanie jest rzeczywistością eschatyczną i ponadhistoryczną, która wymyka się ludzkiemu postrzeganiu ${ }^{17}$. Zmartwychwstały Pan manifestuje swój nowy sposób bytowania wobec wybranych świadków. Łaskawe zjawienia się Chrystusa zmartwychwstałego i rozpoznanie Jego Osoby przez świadków chrystofanii utwierdza ich w przeświadczeniu, że zmartwychwstanie jest dziełem Boga ${ }^{18}$. Ciało Zmartwychwstałego jest realne, nosi na sobie znamiona męki: rany na rękach i nogach oraz ślady przebicia boku. Ślady te są znakami rozpoznawczymi, wskazującymi na identyczność Zmartwychwstałego z Ukrzyżowanym.

\section{OSOBOWY WYMIAR UKAZYWANIA SIE ZMARTWYCHWSTAŁEGO}

Zdaniem E. Kopcia w przekazie Nowego Testamentu można zauważyć schemat opisów chrystotofanijnych: ukazanie się - rozpoznanie - misja ${ }^{19}$. Fakt ukazania został wyrażony przez greckie ófthé, co można tłumaczyć jako czasownik w formie biernej: Bóg uczynił Go widzialnym, Bóg sprawił, że stał się widzialny, lub zwrotnej: uczynił się widzialnym, ukazał się, pozwolił się zobaczyć, dał się widzieć ${ }^{20}$. W Septuagincie formuła ta, używana na określenie aktu objawienia się Boga (np. Rdz 12,7; 17,1; 22,14; 31,13; Wj 3,2.16), uwyraźnia Bożą inicjatywę oraz łaskawy charakter Jego działania. Starotestamentowe teofanie oznaczają osobowe spotkania Boga z człowiekiem

\footnotetext{
${ }^{15}$ E. Kopeć, Chrystofanie jako znaki zmartwychwstania Chrystusa, s. 24; TENŻE, Zmartwychwstanie Jezusa Chrystusa jako realny fakt $i$ wydarzenie zbawcze, s. 272.

${ }^{16}$ E. Kopeć, Zmartwychwstanie Jezusa Chrystusa jako realny fakt $i$ wydarzenie zbawcze, s. $272-273$.

17 E. KOPEĆ, Problematyka zmartwychwstania Chrystusa w apologetyce wspótczesnej, s. $86-87$.

18 Tamże, s. 100.

${ }^{19}$ E. Kopé́, Zmartwychwstanie Jezusa Chrystusa jako realny fakt $i$ wydarzenie zbawcze, s. $272-274$

${ }^{20}$ E. Kopeć, Chrystofanie jako znaki zmartwychwstania Chrystusa, s. 23-24.
} 
(np. Abrahamem, Mojżeszem), do których dochodzi z inicjatywy Jahwe. Identyczność terminologii stosowanej w Biblii na określenie starotestamentowych teofanii i nowotestamentowych chrystofanii pozwala na dostrzeżenie ich nadprzyrodzonego charakteru oraz bogactwa ich istoty. Teofanie uwyraźniaja bowiem zarówno istnienie Boga, jak również Jego zbawcze działanie, które ma miejsce „tu i teraz” i łączy się z rzeczywistą Bożą obecnością.

Inicjatywa w ukazywaniu się uczniom wypływa ze strony Jezusa - ukazuje się On kiedy chce i komu chce. Zmartwychwstały Pan nagle i nieoczekiwanie pozwala się zobaczyć wybranym uczniom i niewiastom. Doświadczenie widzenia Jezusa nie jest wynikiem ich oczekiwań, intensywnej tęsknoty czy wyobraźni, ale jest inicjatywą Zmartwychwstałego, który przychodzi do uczniów i pozwala się zobaczyć. Nowotestamentowe świadectwa podkreślają, że uczniowie są zaskoczeni niespodziewaną obecnością Pana. Spotkań ze Zmartwychwstałym nie można zatem sprowadzić do subiektywnych odczuć uczniów, ale są one realnym doświadczeniem Jego Osoby i życia w nowej egzystencji. W opisach ewangelijnych realność chrystofanii została uwypuklona przez fakt wspólnego posiłku i rozmowy Chrystusa z uczniami. W teologii rezurekcyjnej E. Kopcia powyższe wnioski mają duże znaczenie dla uzasadnienia wiarygodności chrystofanii, pozwalają bowiem jednoznacznie stwierdzić, że spotkania ze Zmartwychwstałym były wydarzeniami realnymi, tzn. pochodziły z zewnątrz i podlegały postrzeganiu zmysłowemu świadków ${ }^{21}$.

Ukazywanie się Zmartwychwstałego uczniom było fenomenem nadzwyczajnym, który początkowo wzbudził w nich lęk i niepewność. Chrystofanie wskazują na nowy sposób egzystencji Pana, objawiają Jego zwycięstwo nad śmiercią. Jako realne doświadczenie uczniów każda z chrystofanii stanowi odrębne wydarzenie na płaszczyźnie czasowej i przestrzennej (chrystofanie dokonują się w wielu miejscach i w różnym czasie), jednak jako misterium wielkanocne stanowia jedno wydarzenie paschalne. Chrystofanie mają charakter osobowych spotkań. Zmartwychwstały nie tylko przychodzi do uczniów, ale także przebywa $\mathrm{z}$ nimi, rozmawia, spożywa posiłek, a nawet pozwala się dotknąć. Wszystko to sprawia, że umacnia się osobowa więź między Nim i uczniami. Ta osobowa relacja została zapoczątkowana w momencie powołania uczniów i była pogłębiana podczas ich towarzyszenia Jezusowi. E. Kopeć, uwyraźniając łaskawy i osobowy charakter ukazywania się zmartwychwstałego

\footnotetext{
${ }^{21}$ E. KOPEĆ, Apologia zmartwychwstania Chrystusa w pierwotnej kerygmie apostolskiej, s. 71; TENŻE, Problematyka zmartwychwstania Chrystusa w apologetyce wspótczesnej, s. 100; TENŻE, Chrystofania w teologii, w: Encyklopedia Katolicka, t. 3, kol. 302; TENŻE, Chrystofanie jako znaki zmartwychwstania Chrystusa, s. 23-24.
} 
Pana pisze: „To sam Bóg chce nawiązać kontakt z człowiekiem, manifestuje swoją obecność i rozpoczyna dialog"22. Takie określenie przez lubelskiego teologa istoty chrystofanii paschalnych oddaje ich personalistyczny i dynamiczny charakter.

\section{PERSONALISTYCZNY CHARAKTER ROZPOZNANIA}

Istotnym elementem chrystofanii paschalnych jest rozpoznanie ukazującej się Osoby. Podobnie jak ukazanie, tak rozpoznanie - w ujęciu pioniera lubelskiej szkoły teologii fundamentalnej - ma personalistyczny charakter. Świadkowie chrystofanii rozpoznają, że przychodzi do nich zmartwychwstały Pan, który wcześniej został ukrzyżowany, umarł i został złożony do grobu. Uczniowie i niewiasty odkrywają, że ukazał się im Jezus Chrystus, który znów żyje. Rozpoznanie dokonuje się stopniowo. Mimo że „widzieli” i „słyszeli” Zmartwychwstałego, to mieli trudności z odkryciem, kim On jest. W zmartwychwstaniu dokonało się bowiem przejście Chrystusa do rzeczywistości nowej, eschatycznej - Jego ludzkie ciało zostało przemienione i uwielbione. Jego nowe życie istotnie różni się od życia ziemskiego, które zostało zapoczątkowane we wcieleniu ${ }^{23}$. Zmartwychwstały Pan żyje poza ziemskimi prawami miejsca i czasu, a Jego ciało nie podlega już śmierci, co trafnie ujmuje św. Paweł: „Chrystus powstawszy z martwych już więcej nie umiera, śmierć nad Nim nie ma już władzy" (Rz 6,9). Wszystko to sprawia, że rozpoznanie tożsamości zmartwychwstałego Pana może się dokonać dzięki Bożej łasce to On pozwala, aby uczniowie Go zobaczyli i rozpoznali.

Kulowski profesor w refleksji teologicznej mocno akcentuje, że zmartwychwstały Jezus należy do rzeczywistości, która jest niedostępna ludzkiemu postrzeganiu zmysłowemu. Dlatego zobaczenie Go jest darem, łaską Bożą daną wybranym. W widzeniu tym uczestniczy cała osoba ludzka, jej zmysły (m.in. wzrok, słuch), rozum, serce, duch ludzki oraz wewnętrzne otwarcie na Boga człowieka. Co ważne, uczniowie jako świadkowie życia i ukrzyżowania Jezusa Chrystusa, do rozpoznania Jego nowego sposobu egzystencji potrze-

\footnotetext{
22 E. Kopé́, Zmartwychwstanie Jezusa Chrystusa jako realny fakt i wydarzenie zbawcze, s. $271-272$.

23 E. KOPEĆ, Problematyka zmartwychwstania Chrystusa $w$ apologetyce wspótczesnej, s. 104; TENŻE, Znaczenie chrystologicznej koncentracji w teologii wspótczesnej, w: Chrystocentryzm w teologii, red. E. Kopeć, Lublin 1977, s. 9.
} 
bują Bożej łaski i wiary ${ }^{24}$. Rozpoznanie Zmartwychwstałego dokonuje się na płaszczyźnie międzyosobowego poznania i dialogu. Magdalena, uczniowie w drodze do Emaus, apostołowie otrzymali od Zmartwychwstałego nie tylko łaskę zobaczenia, ale także rozpoznania, która sprawia, że mogli Go oglądać, słyszeć Jego słowa oraz rozpoznać, że to jest $\operatorname{Pan}^{25}$. Dzięki temu, że zmartwychwstały Jezus ukazał się wiele razy, w różnych miejscach oraz wielu osobom, ich doświadczenia zostają zobiektywizowane, a przez to rezurekcja stała się wiarygodna. Dla rozpoznania Jezusa ważne okazują się Jego słowa-zapowiedzi dotyczące wydania, męki na krzyżu i zmartwychwstania. Odwołują się do tego dwaj mężczyźni w lśniących szatach przy pustym grobie: „Przypomnijcie sobie, jak wam mówił, będąc jeszcze w Galilei: «Syn Człowieczy musi być wydany w ręce grzeszników i ukrzyżowany, lecz trzeciego dnia zmartwychwstanie»" (Łk 24,6-7). Ostatecznie w poznaniu przez wiarę świadkowie chrystofanii dokonują identyfikacji zmartwychwstałego Pana z Jezusem z Nazaretu, który umarł na krzyżu i został pogrzebany. E. Kopeć pisze: „Rozpoznanie polega na odkryciu przez uczniów tożsamości postaci Zmartwychwstałego. Poznają w niej Jezusa z Nazaretu, jako świadkowie Jego życia i ukrzyżowania. «Widzą», że ten, który umarł, żyje" ${ }^{26}$. To odwołanie się przez lubelskiego profesora do odkrycia przez uczniów tożsamości Zmartwychwstałego z Ukrzyżowanym nie pozostawia wątpliwości co do personalistycznego rozumienia przez niego chrystofanii paschalnych.

Ewangelijne opisy wielkanocnych spotkań świadczą o tożsamości Jezusa historii i Chrystusa wiary ${ }^{27}$. Tożsamość ta została objawiona w Jego uwielbionym ciele, jednak swoje źródło ma w osobowym Istnieniu Wcielonego Syna Bożego. W czasie chrystofanii apostołowie rozpoznają tożsamość Osoby Zmartwychwstałego i Ukrzyżowanego. Przeświadczenie uczniów o realnej obecności Zmartwychwstałego nie jest wynikiem jedynie refleksji czy wnioskowania, lecz łączy się z osobowym doświadczeniem Jego Osoby. Te realne i obiektywne doświadczenia, przeżyte i przemyślane przez apostołów, stanowią uzasadnioną podstawę ich wiary, która dała początek chrześcijańskiej wierze.

\footnotetext{
24 E. Kopé́, Nowe próby interpretacji orędzia paschalnego, „Ateneum Kapłańskie” 64(1972), z. 1-2, s. 110-111.

${ }^{25}$ Tamże.

${ }^{26}$ E. KoPé́, Chrystofanie jako znaki zmartwychwstania Chrystusa, s. 25.

${ }^{27}$ E. Kopé́, Zmartwychwstanie Jezusa Chrystusa jako realny fakt $i$ wydarzenie zbawcze, s. $251-252$.
} 


\section{PERSONALISTYCZNE ASPEKTY MISJI, WIARY PASCHALNEJ I ŚWIADECTWA}

Zmartwychwstały Pan jest źródłem i racją wiary apostołów oraz ich świadectwa $^{28}$. Świadkowie chrystofanii jako pierwsi doszli do przekonania, że widzieli Jezusa. Przeświadczenie apostołów o realności zmartwychwstania jest faktem historycznym. Ten etap możemy określić jako rodzenie się wiary w Jezusa Chrystusa, który umarł, zmartwychwstał i żyje. Głoszą oni zmartwychwstanie, gdyż są przekonani o jego prawdziwości. Świadectwo to staje się jeszcze bardziej wiarygodne przez fakt, że wszyscy apostołowie pozostali wierni Chrystusowi i głoszonej prawdzie, nawet za cenę męczeńskiej śmierci ${ }^{29}$.

E. Kopeć uwyraźnia prawdę, że istotnym elementem większości chrystofanii paschalnych jest powierzenie przez Zmartwychwstałego uczniom misji ${ }^{30}$. Apostołowie otrzymali posłannictwo głoszenia Dobrej Nowiny „wszelkiemu stworzeniu" (Mk 16,15-18; por. Łk 24,48-49). Misja ta ma charakter personalistyczny i zbawczy. Uczniowie, nauczając, mają także udzielać „chrztu w imię Ojca i Syna, i Ducha Świętego" (Mt 28,19). W relacji św. Jana Jezusowe posłannictwo obejmuje także odpuszczanie grzechów (J 20,22-23). Czwarty Ewangelista w narracjach chrystofanijnych odnotowuje przekazanie władzy prymacjalnej Szymonowi. Na mocy powierzonej posługi Piotr-Skała ma czuwać nad powierzoną mu owczarnią, czyli Kościołem. Misja powierzona Piotrowi oraz apostołom przez Zmartwychwstałego ma charakter ponadczasowy i eklezjogenetyczny: „Oto ja jestem z wami przez wszystkie dni, aż do skończenia świata" (Mt 28,20). Z perspektywy badań personalistycznych istotne jest także to, że chrystofanie, jako „godzina” narodzin wiary, są też początkiem posłannictwa Kościoła - wspólnoty na wskroś personalnej i personalistycznej ${ }^{31}$. Apostołowie mają we wspólnocie eklezjalnej przedłużać posłannictwo Chrystusa poprzez głoszenie Ewangelii wszystkim narodom i aktualizowanie zbawczego dzieła w mocy Ducha Świętego ${ }^{32}$.

Istotne znaczenie dla wiary chrześcijańskiej ma wiarygodność świadków wydarzeń wielkanocnych. Uczniowie towarzyszyli wiernie Jezusowi w czasie

\footnotetext{
${ }^{28}$ E. KoPé́, Teologia fundamentalna, s. 154-159.

${ }^{29}$ E. KoPEĆ, Zmartwychwstanie Jezusa Chrystusa jako realny fakt i wydarzenie zbawcze, s. 246-247.

${ }^{30}$ E. Kopeć, Świadkowie zmartwychwstania Jezusa Chrystusa, s. 37-41.

${ }^{31}$ E. Kopé́, Zmartwychwstanie Jezusa Chrystusa jako realny fakt i wydarzenie zbawcze, s. $274-275$.

${ }^{32}$ E. Kopeć, Teologia fundamentalna, s. 161.
} 
Jego nauczania i zbawczej działalności. Wprawdzie rozproszyli się i uciekli w chwili Jego pojmania i krzyżowej śmierci, jednak wydarzenia wielkanocne, a szczególnie spotkania ze zmartwychwstałym Panem, umocniły ich wiarę w Jego mesjańskie posłannictwo i zrodziły przekonanie, że On zmartwychwstał i żyje. Entuzjazm wiary apostolskiej znalazł wyraz w odważnym świadczeniu o Zmartwychwstałym. Świadectwa nowotestamentowe potwierdzają, że uczniowie, ukazując nowy sposób egzystencji zmartwychwstałego Pana, czerpią z osobistych doświadczeń i opisują ją jako rzeczywistość realną ${ }^{33}$. Przeżycia paschalne uczniów i ich wiara ma ponadczasowe znaczenie. Wiara kolejnych pokoleń chrześcijan opiera się na świadectwie apostołów i z motywów ich wiary czerpie wieloaspektowe uzasadnienie.

Lubelski profesor zaznacza, że świadkiem zmartwychwstania w Kościele apostolskim mógł być tylko ten, kto doświadczył chrystofanii. Na potwierdzenie tej opinii przywołuje słowa św. Piotra wypowiedziane przy wyborze Macieja: „Trzeba więc, aby jeden z tych, którzy towarzyszyli nam przez cały czas, kiedy Pan Jezus przebywał z nami, począwszy od chrztu Janowego aż do dnia, w którym został wzięty od nas do nieba, stał się razem z nami świadkiem Jego zmartwychwstania" (Dz 1,21-22) ${ }^{34}$. To prawda - zauważa E. Kopeć - że apostołowie, głosząc orędzie wielkanocne, powołują się na bezpośrednią znajomość faktów życia Jezusa, że osobiście przeżyli spotkanie ze Zmartwychwstałym i mówią, że „żadną miarą nie mogą milczeć o tym, co widzieli i słyszeli” (Dz 4,20). Dzięki osobistym doświadczeniom, przeżytym po śmierci Jezusa, mogą oni świadczyć o tych wydarzeniach: są zatem świadkami Zmartwychwstałego ${ }^{35}$. Jednak ich świadectwo o wydarzeniach paschalnych wykracza poza świadectwo historyczne, które polega jedynie na potwierdzeniu historyczności zdarzenia. Apostołowie nie tylko potwierdzają faktyczność przepowiadanych wydarzeń, ale także ukazują ich zbawczy sens, tym samym są świadkami-wyznawcami, a ich świadectwo dokonuje się w mocy Ducha Świętego, którego otrzymali i który - zgodnie z obietnicą Chrystusa - doprowadził ich do pełni prawdy (J 16,13). Dlatego świadectwo apostolskie jest składane na płaszczyźnie wiary, co uwypukla lubelski profesor: „Jest to zupełnie zrozumiałe, że o takim fakcie jak zmartwychwstanie nie można

33 Tamże, s. 155-159.

${ }^{34}$ E. KOPEĆ, Problematyka zmartwychwstania Chrystusa w apologetyce wspótczesnej, s. 99.

${ }^{35}$ E. KoPEĆ, Świadkowie zmartwychwstania Jezusa Chrystusa, s. 5-43; por. K. SKAWIŃSKI, Ku historiozbawczej wizji Zmartwychwstania Jezusa. Pojęcie Zmartwychwstania w ujęciu ks. Edwarda Kopcia, „Roczniki Teologiczno-Kanoniczne” 32(1985), z. 2, s. 41. 
świadczyć wyłącznie na płaszczyźnie historycznej, bez równoczesnego wyznawania tego faktu wiarą"36.

Podsumowując należy stwierdzić, że problematyka rezurekcyjna zajmuje uprzywilejowane miejsce w twórczości naukowej E. Kopcia. Lubelski profesor zmartwychwstanie Jezusa Chrystusa ukazuje holistycznie, mając na uwadze jego wymiar wydarzeniowy i misteryjny, uwypukla przede wszystkim jego historiozbawczy charakter. Biorąc pod uwagę to, że chrystofanie paschalne stanowią najważniejsze znaki wiarygodności rezurekcji Jezusa, lubelski profesor traktuje je zawsze jako wydarzenia realne i obiektywne. Nade wszystko chrystofanie paschalne, podobnie jak starotestamentowe teofanie, maja dla ks. Kopcia charakter osobowy. Spotkania zmartwychwstałego Pana z uczniami są wyrazem głębokiej międzyosobowej relacji, co wyrażają istotne elementy personalistyczne większości chrystofanii: ukazanie się - rozpoznanie - misja. Warto także dodać, że pionierskie opracowanie przez ks. E. Kopcia chrystofanii paschalnych $\mathrm{w}$ kategoriach personalistycznych koreluje $\mathrm{z}$ ich historiozbawczym charakterem, co ma istotne znaczenie dla wykazania wiarygodności rezurekcji Chrystusa.

\section{BIBLIOGRAFIA}

BARTSCH H.W., Das Auferstehuhgszeugnis, sein historisches und sein theologisches Problem, Hamburg 1965.

Benoît P., Passion et résurrection du Seigneur, Paris 1966.

BÜrgener K., Die Auferstehung Jesu Christi von Toten, 3. Aufl. Bremen 1976.

Cantinat J., Réflexion sur la résurrection de Jésus (d'aprés saint Paul et saint Marc), Paris 1978.

DANIÉLU J., La résurrection, Paris 1969.

Durrwell F.X., La résurrection de Jésus. Mystere de salut, ed. 3, Paris 1961.

GEENSE A., Auferstehung und Offenbarug, Göttigen 1971.

GUIBERT P., Il résurrection le troisième jour, Paris 1975.

GuitTon J., Le problème de Jésus. Divinité et Résurrection, Paris 1953.

KAUCHA K., Lubelska szkoła teologii fundamentalnej, w: Encyklopedia 100-lecia KUL, t. 1, Lublin 2018, s. 634-635.

\footnotetext{
${ }^{36}$ E. Kopé́, Świadkowie zmartwychwstania Jezusa Chrystusa, s. 13.
} 
KAUCHA K., Wiarygodność i wiara w ujęciu lubelskiej szkoły teologii fundamentalnej, w: Wiara - wiarygodność, red. D. Wąsek, Kraków 2014, s. 634-635.

KitTel G., Die Auferstehung Jesu, Stuttgart 1937.

KLAPPERT B., Diskussion um Kreuz und Auferstehung, 3. Aufl., Wuppertal 1968.

Koch G., Die Auferstehung Jesu Christi, 2. Aufl., Tübingen 1965.

KolPING A., Wunder und Auferstehung Jesu Christi, Bergen-Enkhein 1969.

Kopeć E., Chrystologia w świetle historii zbawienia, „Ruch Biblijny i Liturgiczny” 6(1953), s. $74-85$.

Kopeć E., Apologia zmartwychwstania Chrystusa w pierwotnej kerygmie apostolskiej, „Roczniki Teologiczno-Kanoniczne" 6(1959), z. 3, s. 57-75.

Kopeć E., Chrystofania w teologii, w: Encyklopedia Katolicka, t. 3, kol. 302-303.

KopeĆ E., Chrystofanie jako znaki zmartwychwstania Chrystusa, „Roczniki Teologiczno-Kanoniczne" 25(1978), z. 2, s. 21-29.

Kopé́ E., Chrystologiczna koncentracja w teologii, „Roczniki Teologiczno-Kanoniczne” 22(1975), z. 2, s. 59-71.

KoPEć E., Ewangelia św. Pawła jako świadectwo o zmartwychwstaniu Chrystusa, w: Ze współczesnej problematyki biblijnej, red. S. Łach, Lublin 1961, s. 93-113.

KoPeć E., Historiozbawczy charakter zmartwychwstania Chrystusa, „Roczniki TeologicznoKanoniczne" 24(1977), z. 4, s. 107-118.

Kopeć E., Nowe próby interpretacji orędzia paschalnego, „Ateneum Kapłańskie” 64(1972), z. 1-2, s. 101-111.

KOPEĆ E., Problematyka zmartwychwstania Chrystusa w apologetyce współczesnej, „Collectanea Theologica" 30(1959), s. 83-108.

Kopeć E., Spotkanie św. Pawła z Chrystusem, „Zeszyty Naukowe Katolickiego Uniwersytetu Lubelskiego" 3(1969), z. 1, s. 45-60.

Kopeć E., Świadkowie zmartwychwstania Jezusa Chrystusa, „Roczniki Teologiczno-Kanoniczne" 7(1960), z. 1, s. 5-43.

KOPEĆ E., Teologia fundamentalna, Lublin $1976^{3}$.

Kopeć E., Wydarzeniowy i misteryjny aspekt zmartwychwstania Chrystusa, w: Teologia nauką o Bogu. Kongres Teologów Polskich, Kraków 1976, s. 225-228.

Kopeć E., Zmartwychwstanie Jezusa Chrystusa jako realny fakt i wydarzenie zbawcze, w: Jezus Chrystus. Historia i tajemnica, red. W. Granat, E. Kopeć, Lublin 1982, s. 246-277.

Kopeć E., Znaczenie chrystologicznej koncentracji w teologii współczesnej, w: Chrystocentryzm w teologii, red. E. Kopeć, Lublin 1977, s. 7-16.

Kopé́ E., Znaczenie personalistycznej koncepcji wiary dla apologetyki współczesnej, „Roczniki Teologiczno-Kanoniczne" 11(1964), z. 2, s. 5-18.

Kremer J., Das älteste Zeugnis von der Auferstehung Christi, Stuttgart 1968.

LeHMANN K., Jesus Christus ist auferstanden, Freiburg i Br. 1975.

LÉON-DufOuR X., Résurrection de Jésus et message pascal, Paris 1971.

LÉON-DufOur X., Sur la résurrection de Jésus, „Recherches de Science Religieuse” 57(1969), s. $583-622$.

MASTEJ J., Dorobek lubelskiej szkoły teologii fundamentalnej w zakresie chrystologii, „Roczniki Teologiczne" 65(2018), z. 9, s. 55-74.

Mastej J., KAUCha K., 100 lat teologii fundamentalnej na KUL, „Przegląd Uniwersytecki” 30(2018), nr 1, s. 22-25.

Mussner F., Die Auferstehung Jesu, München 1969.

RUSECKI M., Elementy personalistycznej teologii fundamentalnej w ujęciu Edwarda Kopcia, „Roczniki Teologiczno-Kanoniczne” 32(1985), z. 2, s. 49-85.

RUSECKI M., Kopeć Edward, w: Encyklopedia 100-lecia KUL, t. 1, Lublin 2018, s. 541-542. 
RUSECKI M., Kopeć Edward, w: Encyklopedia Katolicka, t. 9, kol. 794-795.

RUSECKI M., Kopeć Edward, w: Leksykon Teologii Fundamentalnej, red. M. Rusecki i in., Lublin-Kraków 2002, s. 651-653.

RUSECKI M., Ksiądz prof. dr hab. Edward Kopeć. Życie i działalność naukowo-dydaktyczna, „Roczniki Teologiczno-Kanoniczne” 32(1985), z. 2, s. 7-22.

RUSECKI M., O księdzu profesorze Edwardzie Kopciu i jego wkładzie w polską teologię fundamentalną, w: Teologia wobec zjawisk paranormalnych, red. K. Kaucha, J. Mastej, Lublin 2011, s. 5-13.

RUSECKI M., Zagadnienie personalizmu w pracach badawczych Wydziału Teologii KUL (19681993), „Roczniki Teologiczne” 43(1996), z. 4, s. 249-263.

SCHEFFCZYK L., Auferstehung. Prinzio christlichen Glaubens. Einsiedeln 1976.

Schmitt J., Jésus résuscité dans la prédication apostolique. Paris 1949.

SchoOnenberg P., Wege nach Emmaus. Unser Glaube an die Auferstehung Jesu, Graz 1974.

SKAwIŃSKI K., Ku historiozbawczej wizji Zmartwychwstania Jezusa. Pojęcie Zmartwychwstania w ujęciu ks. Edwarda Kopcia, „Roczniki Teologiczno-Kanoniczne” 32(1985), z. 2, s. 39-50.

SPÖRLEIN B., Die Leugnung der Auferstehung, Regensburg 1971.

WiLCKENs U., Auferstehung. Das biblische Auferstehungszeugnis historisch untersucht und erklärt, Stuttgart 1970.

\section{PERSONALISTYCZNY CHARAKTER CHRYSTOFANII PASCHALNYCH W UJECIU KS. PROF. EDWARDA KOPCIA (1918-1999)}

St r e s z c z e n i e

Artykuł prezentuje personalistyczny charakter chrystofanii paschalnych w ujęciu ks. prof. Edwarda Kopcia, nestora teologii fundamentalnej w Polsce. Podjęty temat został zaprezentowany w czterech punktach: 1 . Chrystofanie paschalne jako wiarygodne znaki zmartwychwstania; 2. Osobowy wymiar ukazywania się Zmartwychwstałego; 3. Personalistyczny charakter rozpoznania; 4. Personalistyczne aspekty misji, wiary paschalnej i świadectwa.

Wychodząc z przekonania, że chrystofanie paschalne stanowią najważniejsze znaki wiarygodności rezurekcji Jezusa, ks. E. Kopeć traktuje je zawsze jako wydarzenia realne oraz obiektywne i prezentuje je wieloaspektowo. Nade wszystko chrystofanie paschalne, podobnie jak starotestamentowe teofanie, mają dla lubelskiego profesora charakter osobowy. Spotkania zmartwychwstałego Pana z uczniami są wyrazem międzyosobowej relacji, co wyrażają istotne elementy większości chrystofanii, a mianowicie: ukazanie się - rozpoznanie - misja. Pionierskie opracowanie przez ks. E. Kopcia chrystofanii paschalnych w kategoriach personalistycznych koreluje $\mathrm{z}$ ich historiozbawczym charakterem, co ma istotne znaczenie dla wykazania wiarygodności rezurekcji Chrystusa.

Słowa kluczowe: Edward Kopeć; Jezus Chrystus; zmartwychwstanie; chrystofanie paschalne. 